\title{
INFLUENCE OF PECULARITIES OF ANATOMICAL STRUCTURE (SHAPE) OF DUODENAL BULB ON THE MECHANISM OF FORMATION OF "KISSING" ULCERS OF PATIENTS WITH CHRONIC NON-ATROPHIC GASTRITIS
}

\author{
Anatoly A. Avramenko \\ PYLYP ORLYK INTERNATIONAL CLASSICAL UNIVERSITY, MYKOLAIV, UKRAINE
}

\begin{abstract}
The aim: To determine of the factors influencing the formation of "kissing" duodenal bulb ulcer in patients with chronic non-atrophic gastritis. Materials and methods: The data of a comprehensive examination of 34 patients with chronic non-atrophic gastritis were analyzed, in which the examination revealed "kissing" ulcers of the duodenal bulb (primary group), and 37 patients with chronic non-atrophic gastritis, in which single ulcers were detected in the bulb (control group). Comprehensive examination included: step-by-step intragastric pH-metry, esophagogastroduodenoscopy, helicobacter infection test (HP) (helicobacter urease test and microscopic examination of stained smears), histological investigations of the gastric stump mucous, material for which was taken during endoscopy from 4 topographical zones: from the middle third of the gastric antrum and body of stomach on the big and small curvature.

Results: In the course of the examination, the presence of chronic non-atrophic gastritis in 100\% of cases was confirmed with a different degree of activity of the inflammatory process on the gastric mucosa, as well as the presence of Helicobacter pylori infection with a high degree of colonization of the gastric mucosa in the absence of a significant difference $(p>0.05$ ) in the stomach zones. It was found that the main difference that can be traced in $100 \%$ of cases is the difference in the anatomical structure of the bulb of the duodenum, namely, the shape: in the control group, the shape and lumen of the duodenal bulb are round, while in the patients of the main group the bulb the duodenum, starting from the pylorus, is stretched toward the large and small curvature, which gives the lumen bulb its oval shape.

Conclusions: "Kissing" ulcers of the duodenal bulb are formed in patients with chronic non-atrophic gastritis only if the patients have a peculiar anatomical structure of the bulb, in which the lumen has an oval shape.
\end{abstract}

KEY WORDS: chronic non-atrophic gastritis, oval shape of duodenal bulb, "kissing” ulcers

Wiad Lek. 2020;73(12 p. I):2568-2571

\section{INTRODUCTION}

Peptic ulcer is one of the most common pathologies of the upper gastrointestinal tract, which is often accompanied by a number of complications: bleeding, which accounts for $18-47 \%$ of all urgent diseases of the abdominal cavity; pyloroduodenal stenosis, which averages 15-30\%; perforation, which occurs in 10-30\% of patients with peptic ulcer of the stomach and duodenum [1-11]. The discovery of Helicobacter pylori (HP) in the 1983 by Australian scientist B. Marshall and J. R. Warren changed views on etiology of diseases such as chronic non-atrophic gastritis (chronic gastritis type b), peptic ulcer disease and stomach cancer [12-22]. As for the peptic ulcer disease, many questions related to the pathogenesis of this disease, remain still unanswered and, in particular, the question: "Why do some patients with peptic ulcer disease of duodenum in bulb have one ulcer formed, while others-two?". In the available literature, we have not found an answer to this question, which was the reason for our research.

\section{THE AIM}

To determine of the factors influencing the formation of "kissing" duodenal bulb ulcer in patients with chronic non-atrophic gastritis.

\section{MATERIALS AND METHODS}

On the basis of the clinical division of the problem lab concerning the questions of chronic Helicobacter pylori infection of the Petro Mohyla Black Sea National University comprehensive survey data of 34 patients with chronic non-atrophic gastritis were analyzed. During the examination "kissing" ulcers of duodenal bulb" (primary group) had been found. 37 patients with chronic non-atrophic gastritis had single ulcers (control group). The age of patients ranged from 25 to 54 years old (average age amounted to $30.2 \pm$ 1.19 years); male $-48(67.6 \%)$, female $-23(32.4 \%)$.

The study was conducted in accordance with the basic bioethical provisions of the Helsinki Declaration of the World Medical Association on the ethical principles of 
Table I. The level of acidity in patients of primary and control group

\begin{tabular}{ccccc}
\hline \multirow{2}{*}{ The level of acidity } & $\begin{array}{c}\text { Primary group } \\
(\mathbf{n}=\mathbf{3 4 )}\end{array}$ & $\begin{array}{c}\text { Control group } \\
(\mathbf{n}=\mathbf{3 7})\end{array}$ \\
\cline { 2 - 5 } & Number of patients & $\%$ & Number of patients & $\%$ \\
\hline Hyperacidity expressed & 2 & 5,9 & 2 & 5,4 \\
\hline Hyperacidity moderate & 7 & 20,6 & 4 & 10,8 \\
\hline Normacidity & 12 & 35,3 & 14 & 37,8 \\
\hline Hypoacidity moderate & 8 & 23,5 & 9 & 24,4 \\
\hline Hypoacidity expressed & 5 & 14,7 & 8 & 21,6 \\
\hline Anacidity & 0 & 0 & 0 & 0 \\
\hline
\end{tabular}

Note: $n$-the number of studies

Table II. The topography of the localization of ulcerous defects in the duodenal bulb of patients of primary and control groups

\begin{tabular}{|c|c|c|c|c|c|c|c|c|}
\hline \multirow{3}{*}{ Groups } & \multicolumn{8}{|c|}{ The topography of the localization of ulcerous defects } \\
\hline & \multicolumn{2}{|c|}{ Front wall } & \multicolumn{2}{|c|}{ Back wall } & \multicolumn{2}{|c|}{ Large curvature } & \multicolumn{2}{|c|}{ Small curvature } \\
\hline & Quantity & $\%$ & Quantity & $\%$ & Quantity & $\%$ & Quantity & $\%$ \\
\hline $\begin{array}{l}\text { Primary } \\
(\mathrm{n}=34)\end{array}$ & 34 & 100 & 34 & 100 & 0 & 0 & 0 & 0 \\
\hline $\begin{array}{l}\text { Control } \\
(\mathrm{n}=37)\end{array}$ & 9 & 24,4 & 14 & 37,8 & 8 & 21,6 & 6 & 16,2 \\
\hline
\end{tabular}

Note: $n$-the number of studies

scientific 549 medical research involving human (2013) and the order of the Ministry of Health of Ukraine No. 690 dated September 23, 2009, which was confirmed by the findings of the meeting of the Ethical Commission of Petro Mohyla Black Sea National University, Nikolaev

No. 12 dated December 11,2019. A written consent was obtained from the patients for the study.

Comprehensive examination included: step-by-step enteric $\mathrm{pH}$-metry based on V.N. Chernobrovii methodology, esophagogastroduodenoscopy (EGDS) by generally accepted method, double HP'S testing: test for urease activity and microscopy of stained by Giemsa smears, material for which was taken during endoscopy from 4 topographical zones: from the middle third of the gastric antrum and body division on the big and small curvature according to our worked out methodology, which allows you to define both the presence of intracellular "depot" of HP infection as well as histological studies of the gastric mucosa, the material for which is taken from the same zone, using a generally accepted method taking into account recent classifications $[23,24]$.

Sequence of the survey: first patients had $\mathrm{pH}$-metry and after-EGDS with biopsy material for testing on HP and histological studies of the stomach mucosa. The study was conducted in the morning, fasting, in 12-14 hours after the last meal. The data obtained were processed statistically using Student's t-test with the computation of averages (M) and perhaps the likelihood of deviations (m). The changes were considered to be statistically significant at $\mathrm{p}<0.05$. Statistical calculations were performed using Excel spreadsheets for Microsoft Office.

\section{RESULTS}

Data obtained during the conduct of $\mathrm{pH}$-metering, are shown in table I.

As can be seen from this table, ulcer formation in both groups occurred at all levels of gastric acidity with a predominance of low acidity (in the primary group - 13 (38.2\%) in the control group-17 (46\%) patients), whereas at high acidity is less (in the primary group- $9(26.5 \%)$ in the control group - $6(16.2 \%)$.

When carrying out the EGDS active ulcerative process in the duodenum was found in $100 \%$ of patients of both groups; 8 (23.5\%) patients of the primary group and 11 (29.7\%) patients of the control group had suffered in the past manifestations of ulcers duodenal bulb as scar deformity of varying degrees of severity. Data on the location of ulcers for topographical zones bulbs duodenal ulcer are shown in table II.

As can be seen from the table "kissing" ulcer are not in vain have such a title: they are arranged symmetrically opposite one another on front-back walls, whereas ulcerative defects among patients of the control group are not only in these areas, but also on small and large curvature.

When analyzing data of histological investigations, of all patients in $100 \%$ of cases, have confirmed the existence of chronic non-atrophic gastritis in both active and inactive stages of varying degrees of severity.

When testing on HP Helicobacter infection was detected in $100 \%$ of cases. Data on the extent of the gastric mucosa semination with HP infection on topographical zones of the stomach of patients of primary and control groups are shown in table III. 
Table III. Degree of gastric mucosa semination with HP infection on topographical zones main of patients of primary and control groups

\begin{tabular}{|c|c|c|}
\hline \multirow{2}{*}{ Groups } & \multicolumn{2}{|c|}{ Degree of gastric mucosa semination with HP infection on topographical zones $(+) /(M \pm m)$} \\
\hline & Antrum department & Body of the stomack \\
\hline Primary group & a) $2,13 \pm 0,27$ & a) $2,24 \pm 0,27$ \\
\hline$(n=34)$ & b) $2,11 \pm 0,27$ & b) $2,25 \pm 0,27$ \\
\hline Control group & a) $2,10 \pm 0,25$ & a) $2,13 \pm 0,25$ \\
\hline$(n=37)$ & b) $2,16 \pm 0,25$ & b) $2,18 \pm 0,25$ \\
\hline
\end{tabular}

Note: $n$-the number of studies, a)-large curvature, b)-small curvature

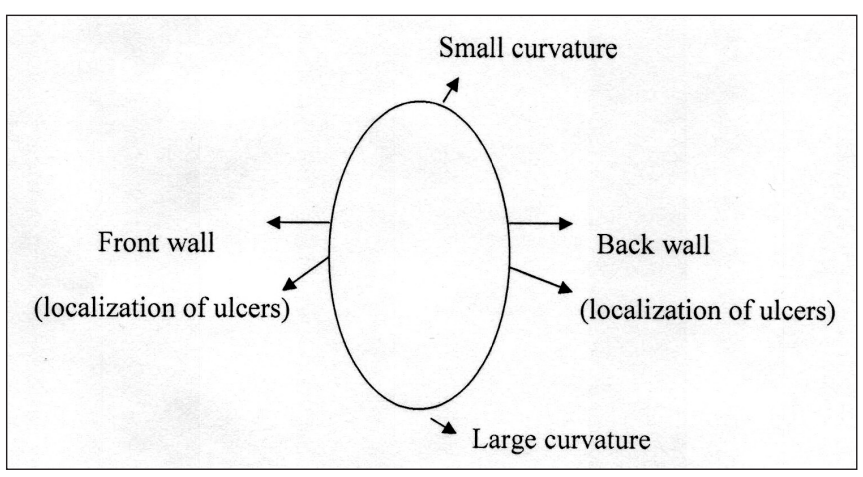

Fig 1. Peculiarities of the form of lumen bulb of the duodenum and localization of ulcerous defect of patients of primary group

Comparative analysis of data on the medium level of semination with HP infection on gastric mucosa on similar topographical areas of patients of primary and control groups, reliable differences weren't found ( $p>0.05)$.

The main difference, which can be seen in $100 \%$ of cases, is the distinction of the anatomical structure of the duodenal bulb-shape: control group patients form and lumen bulb of the duodenum have round shape, whereas in patients from primary group duodenal bulb, starting from the gatekeeper, is elongated in the direction of big and small curvature that gives clearance of bulb oval shape. Peculiarities of the form of lumen bulb of the duodenum and localization of ulcerous defects of patients of the primary group are represented on Picture 1 .

\section{DISCUSSION}

This phenomenon can be explained in terms of laws for fluid. When you change the shape of the bread pan (move from large containers-stomach into the tube of duodenal ulcer with much smaller cross-section), which passes under the pressure gas and gas density changes. Gas in the stomach is residual ammonia (RA)-ammonia, which was formed out of food urea under the influence of urease enzyme HP infection and has not been used to neutralize the hydrochloric acid around the bacteria. Receipt of RA in the duodenum from the stomach under high pressure occurs either at the expense of hyperkinesia (enhanced peristalsis of stomach under stress) ("piston" effect), or due to the sharp rhythmic compression of the stomach during physical exercise or massage (effect of "bellows") or a combination of both effects [12]. In a situation with an oval shape of the duo- denal bulb gas density will be more in the central and front walls, where, according to a new theory of ulcer formation theory "caustic alkali spit" and conditions are formed for the formation of a grout containing a high concentration of sodium ammonium hydroxide, contact with which leads to damage of the mucosa of the duodenum with formation of symmetric ulcerous defect [12].

\section{CONCLUSIONS}

"Kissing" ulcers of the duodenal bulb are formed in patients with chronic non-atrophic gastritis only if the patients have a peculiar anatomical structure of the bulb, in which the lumen has an oval shape.

\section{REFERENCES}

1. Sovcov S.A. Vybor sposoba lecheniya probodnoj gastroduodenalnoj yazvy [The choice of treatment for perforated gastroduodenal ulcers]. Hirurgiya. 2015;11:41-45. (in Russian).

2. Gadzhiev D.N., AllahverdievV.A., Sushkov S.V. et al.Vliyanie citokinoterapii na rezultaty hirurgicheskogo lecheniya bolnyh s ostrym yazvennym gastroduodenalnym krovotecheniem [The effect of cytokine therapy on the results of surgical treatment of patients with acute ulcerative gastroduodenal bleeding]. Hirurgiya. 2016; 6: 57 - 61. (in Russian).

3. Lebedev N.V., Klimov A.E., Petuhov V.A. Povtornyj endoskopicheskij gemostaz kakalternativa hirurgicheskomu lecheniyu bolnyh syazvennymi gastroduodenalnymi krovotecheniyami [Repeated endoscopichemostasis as an alternative to surgical treatment of patients with gastroduodenal ulcer bleeding]. Hirurgiya. 2016; 6:52 - 56. (in Russian).

4. Veligockij N.N., Komarchuk V.V., Trushin A.S. et al. Individualnoaktivnaya taktika pri yazvennyh krovotecheniyah [Individually active tactics for ulcerative bleeding]. Harkivska hirurgichna shkola. 2016; 2(77): 149 - 151. (in Russian).

5. Bojko V.V., Krivorotko I.V., Groma V.G. Rezultaty i problemnye voprosy lecheniya ostryh yazvennyh zheludochno-kishechnyh krovotechenijza poslednie 15 let. Harkivska hirurgichna shkola [Results and problematic issues in the treatment of acute gastrointestinal bleeding in the past 15 years.]. 2016; 2(77): 141- 145. (in Russian).

6. Beburishvili A.G., Panin S.I., Mihajlov D.V. et al. Vozmozhnosti konservativnogo lecheniya probodnoj yazvy [Possibilities for conservative treatment of perforated ulcers]. Hirurgiya. 2016; 5:69 - 73. (in Russian).

7. Gadzhiev D.N., Allahverdiev V.A., Sushkov S.V. et al. Sostoyanie mestnyh i sistemnyh pokazatelej immunnogo, citokinovogo i antioksidantnogo statusa pri ostryh yazvennyh gastroduodenalnyh krovotecheniyah [The state of local and systemic indicators of the immune, cytokine and antioxidant status in acute ulcerative gastroduodenal bleeding]. Hirurgiya Ukrayini. 2015; 3: 44 - 48. (in Russian). 
8. Odarchenko S.P., Odarchenko L.V. Diagnostichna ta likuvalna taktika pri perforaciya shlunkovih virazok [Diagnostic and therapeutic tactics for perforation of gastric ulcers]. Hirurgiya Ukrayini. 2017; 2: 116-124. (in Ukrainian).

9. Ratchik V.M., Shevchenko B.F., Tarabarov S.O. et al. Endoskopichna balonna piloro- ta duodenoplastika v likuvanni hvorih zi stenozom piloroduodenalnoyi zoni virazkovogo genezu [Endoscopic balloon pyloric and duodenoplasty in the treatment of patients with stenosis of the pylorduodenal zone of ulcerative genesis]. Hirurgiya Ukrayini. 2017;4:76 - 82. (in Ukrainian).

10. Gadzhiev D.N., Sushkov S.V., Allahverdiev V.A. Immunnye narusheniya pri ostryh yazvennyh gastroduodenalnyh krovotecheniyah [Immune disorders in acute ulcerative gastroduodenal bleeding]. Hirurgiya. 2015; 6: 32 - 34. (in Russian).

11. Burmak Yu.G., Bilokobilska D.V. Dinamika zmin metabolichnih pokaznikiv u ambulatornomu likuvanni hvorih na peptichnu virazku dvanadcyatipaloyi kishki u poyednanni z essencialnoyu gipertenziyeyu [Dynamics of changes in metabolic parameters in outpatient treatment of patients with peptic ulcer of the duodenum in combination with essential hypertension.]. Semejnaya medicina. 2015; 3 (59): 199-200. (in Ukrainian).

12. Avramenko A.A., Gozhenko A.I., Gojdyk V.S. et al. Yazvennaya bolezn (ocherki klinicheskoj patofiziologii) [Peptic ulcer (essays on clinical pathophysiology)]. Odessa: 000 «RA «ART-V».2008: 304. (in Russian).

13. Babak 0.Ya., Bashkirova 0.Ya. Antihelikobakternaya terapiya: akcent na probiotiki [Helicobacter pylori therapy: emphasis on probiotics]. Ukrayinskij terapevtichnij zhurnal. 2015; 1: 91 - 94. (in Russian).

14. Borodach A.V. Sovremennaya koncepciya yazvennoj bolezni: naskolko ona obosnovana [The modern concept of peptic ulcer: how substantiated is it]. Hirurgiya. 2013; 10: 38- 42. (in Russian).

15. Dorofeev A.E., Rudenko N.N., Agibalov A.N et al.. Infekciya Helicobacter pylori u bolnyh s funkcionalnoj dispepsiej i effektivnost eyo eradikacii $v$ Doneckom regione [Helicobacter pylori infection in patients with functional dyspepsia and the effectiveness of its eradication in the Donetsk region]. Vrachebnoe delo. 2014; 11:119-121. (in Russian).

16. Isakov V.A., Domaradskij I.V. et al. Helikobakterioz [Helicobacteriosis]. M.: ID Medpraktika-M. 2003: 412. (in Russian).

17. KomarchukV.V. Citotoksicheskie shtammy Helicobacter pylori u bolnyh s oslozhnyonnymi formami yazvennoj bolezni v sochetanii s reflyuksom [Cytotoxic strains of Helicobacter pylori in patients with complicated forms of peptic ulcer in combination with reflux]. Harkivska hirurgichna shkola. 2015; 2(71): 6 -10. (in Russian).

18. Maev I.V., Samsonov A.A., Andreev D.N. et al.. Klinicheskoe znachenie infekcii Helicobacter pylori [The clinical significance of Helicobacter pylori infection]. Klinicheskaya medicina. 2013; 8: 4 -12. (in Russian).

19. Samsonov A.A., Grechushnikov V.B., Andreev D.N. et al. Ocenka farmakoekonomicheskih pokazatelej lecheniya pacientov $s$ zabolevaniyami, associirovannymi s Helicobacter pylori [Evaluation of pharmacoeconomic indicators for the treatment of patients with diseases associated with Helicobacter pylori]. Terapevticheskij arhiv. 2014:8:56-61. (in Russian).

20. Cimmerman Ya.S., Zaharova Yu.A., Vedernikov V.E. Sravnitelnaya ocenka diagnosticheskih testov opredeleniya Helicobacter pylori i spektr mukoznoj mikroflory zheludka pri gastrite i yazvennoj bolezni [Comparative evaluation of diagnostic tests for determining Helicobacter pylori and the spectrum of mucous microflora of the stomach in gastritis and peptic ulcer]. Klinicheskaya medicina. 2013; 4: 42- 48. (in Russian).
21. Cukanov V.V., Amelchugova 0.S., Kasparov E.V. et al. Rol eradikacii Helicobacter pylori v profilaktike raka zheludka [The role of Helicobacter pylori eradication in the prevention of gastric cancer]. Terapevticheskij arhiv. 2014; 8: 124-127. (in Russian).

22. Korotkevich A.G. Sovremennaya koncepciya yazvennoj bolezni: vzglyad endoskopista [The modern concept of peptic ulcer: an endoscopist's view.]. Hirurgiya. 2014; 11: 55 - 59. (in Russian).

23. Avramenko A.A. Dostovernost stul-testa pri testirovanii bolnykh khronicheskim khelikobakteriozom pri nalichii aktivnykh ineaktivnykh form khelikobakternoy infektsii na slizistoy obolochke zheludka [Reliability of stool test when testing patients with chronic Helicobacter pylori in the presence of active and inactive forms of Helicobacter pylori infection on the gastric mucosa]. Suchasna gastroyenterologíya. 2014; 3 (77): 22-6. (in Russian).

24. Kímakovich V.Y., Nikishaev V.I. et al. Yendoskopiya travnogo kanalu. Norma, patologiya, suchasni klasifikatsiyi [Endoscopy of the digestive canal. Norm, pathology, modern classifications]. Lviv: Vidavnitstvo Meditsina Svítu, 2008: 208. (in Ukrainian).

The work is a fragment of research work "Development of information and communication technologies in the system of medical examinations of seamen", the state registration number 0109 U008375.

\section{ORCID and contributionship:}

Anatoly A. Avramenko: 0000-0002-9652-089X $X^{A, B, C, D, E, F}$

\section{Conflict of interest:}

The Author declare no conflict of interest.

\section{CORRESPONDING AUTHOR}

\section{Anatoly A. Avramenko}

Pylyp Orlyk International Classical University

118 Chkalova st., apartment 4, 54003 Mykolaiv, Ukraine

tel: +380976371807

e-mail: aaahelic@gmail.com

Received: 18.12 .2019

Accepted: 15.09 .2020

A - Work concept and design, B - Data collection and analysis, C - Responsibility for statistical analysis, D-Writing the article, $\mathbf{E}$-Critical review, $\mathbf{F}$ - Final approval of the article 